\title{
Serological Test for Surra Cases in Lombok Island
}

\author{
Ekawasti $\mathrm{F}^{1}$, Wardhana $\mathrm{AH}^{1}$, Sawitri $\mathrm{DH}^{1}$, Dewi DA ${ }^{1}$, Akbari RA ${ }^{2}$ \\ ${ }^{1}$ Indonesian Research Center for Veterinary Science \\ Jl. RE Martadinata No. 30, Bogor 16114, West Java, Indonesia \\ ${ }^{2}$ Faculty of Veterinary Medicine, Bogor Agriculture University, Jl. Agatis, Dramaga, Bogor \\ fitrineekawasti@gmail.com
}

\begin{abstract}
Surra or trypanosomosis caused by Trypanosoma evansi (T. evansi) is one of the most important livestock disease globally causing significant economic losses. Lombok Island possess high population of livestock but is endemic for surra. Diagnosis of surra by parasitological methods are considered easy, rapid and economic. However, the parasitological methods are insensitive to detect trypanosomes in all infested animals, particularly in case of low parasitaemia and chronic form of the disease. A chronic infestation of surra is often associated with severe production losses, but being subclinical the condition is often unrecognised. Accordingly, a rapid, sensitive and simple serological test such as the card agglutination Trypanosomiasis test / T. evansi (CATT/T. evansi) is required, especially in Lombok Island. The objective of this study was to determine serological prevalence of $T$. evansi based on CATT/T. evansi analysis. Samples were collected from cattle in three different districts in Lombok Island, i.e. West lombok, East Lombok and Central Lombok. Testing of samples with CATT/T. evansi was carried out following the instructions of the manufacturer. Of 114 cattle sera, 21.6\% in West Lombok, 53.8\% in East Lombok and 53.8\% in Central Lombok were positive. This study indicated that the serological prevalence of Surra in Lombok was considered high, and a further confirmation by molecular methods is required.
\end{abstract}

Key Word: Surra, Prevalence, Serological Test, CATT, Lombok

\section{INTRODUCTION}

The government's target of self-sufficiency in beef and cattle meets some resistances. One of them is the spread of a disease affecting cattle. Animal health is one of the keys to success on efforts to increase the productivity of livestock. Incidence of the disease in cattle can potentially cause a decrease in the rate of productivity of livestock, causing economic losses in livestock (Patra 2007; Kertawirawan \& Adijaya 2012). Diseases attacking cattles remains a major problem encountered in the livestock industry. In Indonesia, parasitic diseases have less attention from the farmers (Sudarisman 2006).

A blood parasite infesting most of mammals, especially livestock and causing high mortality and morbidity in cattle, horses and camels is Trypanosoma evansi (T. evansi). It generates Surra (trypanosomiasis) which is the most important single cause of economic losses in cattle production. Livestock agency of Sumba Timur (2012) stated that more than 4,268 cattle were vurnerable from Surra and 1,760 livestock died in the period of 20102012. The estimation of economic losses due to Surra attack in January to June 2012 was reported Rp. 1.4165 billion and if there is no treatment for the livestock, it will reach Rp. 167.224 billion.

In addition, the parasite is an animal pathogen as well as the most widely distributed in the world. Surra is transmitted through the bite of blood-sucking flies (haematophagus flies) and it has been spread sporadically in Indonesia since 1897. The mechanical vectors of Surra in Indonesia are Tabanus, Haematopota, and Chrysops, Stomoxys, Musca flies. Haematobia can also be a vector at the time of the fly population is increasing in the region (Desquesnes et al. 2013). 
Surra is most likely to affect horses, cattle, buffalo, pigs, and dogs. The prevalence of the disease in Buffalo in Sumatra, Java, South Kalimantan, Lombok Island, South Sulawesi, and North Sulawesi ranging was between 5.8 to $7 \%$. Surra has been endemic in various regions in Indonesia, such as Banten, East Kalimantan, South Kalimantan, West Nusa Tenggara, East Nusa Tenggara, South Sulawesi, West Java, and West Sumatra. West and East Nusa Tenggara are central livestock regions in Indonesia, however some regions are endemic surra, so that it needs to pay attention to suppress the morbidity/mortality of livestock (Sutama 2008; Santosa et al. 2013).

Throughout the years 2012-2013 until the beginning of 2014 as many as 390 ponytail horse in Sumbawa died due to Surra, while there is no any report from the neighbour island, Lombok. Surra shows special problems with regard to diagnosis, the clinical signs are not typical (pathognomonis) and the standard techniques for the detection of trypanosomes are not sufficiently sensitive (Tran et al. 2009). Although significant improvement have been made recently on diagnosis, a high proportions of infections remains undetected as the chronic, more common form of the disease is often a parasitamic (Brown \& Torres 2008).

Diagnosis is generally based on demonstration of the causative agent. Laboratory testing is necessary to confirm the causative agent by the standard trypanosome parasitological methods, serological tests have also been developed to detect antibodies (Radostits et al. 2007). Parasitological techniques such as Giemsa stained thin smears or thick drops and the microhaematocrit centrifugation technique (mHCT), are commonly used for the diagnosis of surra, but their sensitivity is low due to the fluctuating of parasitemia level, particularly during the chronic stage of the disease (Büscher 2014). Therefore, serological test based on the detection of $T$. evansi specific antibodies is recommended by the world organization for animal health (Organization Internationale des Epizooties, OIE) (OIE 2012). The CATT/T. evansi based on the RoTat 1.2 VAT is a quick and easy test which can be performed under field conditions for serological diagnosis of surra. Even though Ab-detection tests are sensitive, it cannot distinguish current from cured or past infections.

The serological test such as the CATT is used for the detection of antibodies circulating in the serum. The test could be used under both laboratory and field conditions. It is a quick, simple and easy to perform and sensitive method. However, serological techniques are not always distinguishing current from past infection due to the prolonged persistence of antibodies in the blood oftreated animals (Eyob \& Matios 2013). As an alternative to parasitological tests, serological immunoassays can be applied for diagnosis of surra. Non-specific antibody tests like the formol gel, the mercuric chloride and the thymol turbidity test are routinely used for screening surra in poor-resource laboratories. More sophisticated antibody detection tests such as the card agglutination test (CATT/T. evansi) (Jahan et al. 2015).

Within the mammalian host, the cell membrane of thetrypanosomeis covered by a monolayer of variant surface glycoprotein (VSG). This VSG coat is highly immunogenic and induces a strong humoral immune response in the host. As a result, trypanosomes are recognised by VSG-specific antibodies are distroyed (Roge at al. 2014; Horn 2014).

The serological test formats complies with the ASSURED criteria (affordable, sensitive, specific, user-friendly, rapid, equipment-free and delivered) (Mabey et al. 2004). Therefore, the development of an ASSURED serodiagnostic test for surra remains necessary (Büscher 2014). The CATT is used for the detection of antibodies circulating in the serum of infected and the test was found to be a good serological test in the laboratory and field. It is also easy to use in day to day diagnosis. Testing with CATT technique has 
higher sensitivity than the wet smears or buffy coat, MIT technique and MHCT (Magnus et al. 2002; Abdel-Rady 2008; Babeker \& Elrasoul 2014).

The present work aimed to determine a serologycal prevalence of Surra in cattle raised in Lombok Island based on CATT/T.evansi test.

\section{MATERIAL AND METHODS}

\section{Sample collection}

A total of 114 blood sample was collected from cattle in West, East and Central Lombok regions. Samples collected using $10 \mathrm{ml}$ plain vacutainer tubes were allowed to clot and then serum was harvested after $24 \mathrm{~h}$. In the morning the blood samples were centrifuged at $1500 \mathrm{rpm}$ for 10 minutes to separate serum. Each serum sample was collected in eppendorf tubes using sterile pasteur pipette. Serum samples were stored at cold temperature $\left(4^{\circ} \mathrm{C}\right)$ in a sealed container and protected from light. These serum samples were preserved at $-20^{\circ} \mathrm{C}$ until they were used for detection of trypanosome antibodies using CATT/T. evansi test (Reid 2002).

\section{Serological test by card agglutination trypanosomiasis test (CATT)}

CATT/T. evansi was used as one of the index tests. It is one of the OIE recommended tests for $T$. evansi-specific antibody detection CATT/T. evansi was carried out according to the instructions of the manufacturer with serum diluted 1:8 in CATT diluent.

Serum samples were tested using the card agglutination for trypanosomosis test CATT/T. evansi ${ }^{\circledR}$ following the instructions of the manufacturer (laboratory of serology, institute of tropical medicine,Antwerp, Belgium). The CATT/T.evansi is a direct rapid card agglutination test, which uses formaldehyde fixed, freeze-dried trypanosomes expressing a predominant variable antigen type of $T$. evansi (RoTat 1.2) stained with coomassie blue (Bajyana Songa \& Hamers 1988). Accordingly $20 \mu 1$ of serum, diluted 1:8 in CATT-buffer until $140 \mu \mathrm{l}$, was pipetted onto a reaction zone of a plastic coated test card and then added with one drop (about $45 \mu \mathrm{l}$ ) of CATT reagent. The reaction mixture was spread out by a clean stirring rod and allowed to react on a card test rotator for $5 \mathrm{~min}$ at $70 \mathrm{rpm}$. Blue granular deposits reveal a positive reaction visible to the naked eye (OIE 2012).

Reagents and accessory materials were obtained from the Institute of Tropical Medicine (Antwerp, Belgium). A complete test kit for 250 screening tests contains the following: 6 vials CATT- antigen, 1 vial 1 positive control, 1 vial negative control, and 1 vial CATT-buffer (plate 1). The reagents for the test are mixed. A $2.5 \mathrm{ml}$ of CATT buffer was added to a vial of freeze dried CATT antigen using sterile syringe. The vial was then shaken for a few seconds so as to obtain a homogeneous suspension. $0.5 \mathrm{ml}$ of CATT buffer was added to the vials of positive and negative controls using respectively sterile syringe. On a test area of the card, $20 \mu \mathrm{l}$ of the nondiluted serum was added the well containing the homogenized CATT antigen (approximately $45 \mu 1$ ). After tilting the card gently. The test results will appear in the form of granules agglutination reaction where blue will be seen as a positive sign of reaction. Agglutination was observed and the degree of agglutination was determined as follows: Very strong agglutination (+++); Strong agglutination (++); Moderate agglutination (+); and Absence of agglutination (-). 


\section{RESULTS AND DISCUSSION}

\section{Serum collection}

These cattle serum samples from three districts in Lombok was found 114 samples to preparation for serological test (Tabel 1.).

Table 1. Serum samples from cattles in Lombok

\begin{tabular}{lc}
\hline \hline District & Total samples (cattles serums) \\
\hline West Lombok & 74 \\
East Lombok & 20 \\
Central Lombok & 20 \\
\hline Total & 114 \\
\hline
\end{tabular}

\section{Serological test}

Serological tests have been developed and evaluated for diagnosis of trypanosomosis. The antibody-detecting tests such as the CATT/T. evansi so that, detection of infected cattles by serological test (CATT) revealed 35.7\% (30/114) positive (Tabel 2.).

Table 2. The degree of intensity of aglutination of samples in CATT

\begin{tabular}{|c|c|c|c|c|c|}
\hline \multirow{2}{*}{ District } & \multicolumn{4}{|c|}{ "Degree of agglutination } & \multirow{2}{*}{ Positive percentage $(\%)$} \\
\hline & +++ & ++ & + & - & \\
\hline West Lombok & 0 & 2 & 14 & 58 & 21.6 \\
\hline East Lombok & 1 & 2 & 4 & 13 & 35.0 \\
\hline Central Lombok & 0 & 2 & 5 & 13 & 35.0 \\
\hline Total & 1 & 6 & 23 & 84 & 35.7 \\
\hline
\end{tabular}

-: Absence of agglutination; +: Moderate agglutination; ++: Strong agglutination; +++: Very strong agglutination

The CATT/T.evansi test showed that out of 114 examined catle $30(26,32 \%)$ heads were found to be seropositive to $T$. evansi with various grade of agglutinatins. Of 30 seropositive, moderate agglutination (+) was the highest in prevalence, revealing $76.67 \%$, followed by strong and very strong agglutinations for $20.00 \%$ and $3.33 \%$. It indicated that cattle in Lombok Island has been infected by $T$. evansi either in the past or present time. In addition, the result also revealed that the titers of antibody in the sera were not high enough which might be a reflection of the chronicity of the infection. The various results in this study might be due to the variations in the ecology of area, season, vector abundance, number of defenitive and reservoir, host, and virulence of $T$. evansi distribute in Lombok Island. Best on the regions, Central and East Lombok showed relatively higher prevalence to Surra $35.0 \%$ for each (7/20) than West Lombok 21.6\% (16/74). In East Lombok 35.0\% (7/20) and 35.0\% (7/20) in Central Lombok were infected T. evansi by the CATT/T.evansi, respectively (Table 2).

The CATT/T.evansi test was highly sensitive but was not strictly species-specific (Babeker \& Elrasoul 2014). This is in agreement with the findings of Hagos et al. (2009), who reported higher serological prevalence of trypanosomosis than its parasitological. The CATT/T.evansi is a rapid serological test that allows screening of large populations for 
trypanosome specific antibodies. Only those tests with a positive CATT result need then be subjected to time-consuming parasitological examinations. It is a quick, simple and easy to perform and relatively highly more sensitive and spensitive for detection of $T$. evansi infection than the wet smears or buffy coat. However, serological techniques are not always distinguishing current from past infection due to the prolonged persistence of antibodies in the blood of treated animals. The method is mainly used for serological testing on the basis of population, not individual and can be used for serological testing on a subclinical infection or chronic phase and then be followed the molecular test by a PCR test to confirm the agent T. evansi (Abdel-rady 2008; Tran et al. 2009).

The CATT/T.evansi detects IgM and is particularly useful early in the course of the disease. The trypanolysis test may be employed to confirm positive results, and immunofluorescent assays can be used with small numbers of samples. All serological tests have not been validated or standardized for each species, and cross reactions can occur with other trypanosomes (CFSPH 2015). The technique is believed to be able to detect IgM which occurs early in infection, in contrast to the ELISA technique used to detect Ig G (Aquino et al. 2010). According Desquesnes et al. (2013), these two techniques can be done together in order to obtain a powerful diagnostic conclusions. CATT/T. evansi not suitable for active case detection (Buscher et al. 2014). The method is sensitive detection for antibodies against $T$. evansi in domestic animals. Nevertheless, further research is necessary to increase the specificity of the test and to assess its diagnostic accuracy when applied on whole blood under field conditions (Birhanu et al. 2015).

Lower prevalence rate of the present finding might be due to the variations in the ecology of the study areas and seasons of the year when the study was conducted. The present study provides useful baseline data on the prevalence of trypanososmosis in the study area (Aregawi et al. 2015). It is clear that season has direct effect on the distribution of biting flies, which are responsible for the mechanical transmission of $T$. evansi. The current study was conducted during the dry season when the biting fly population is low. Furthermore, local epidemics of surra occur when conditions are favorable for the spread of infection with $T$. evansi, such as when many animals are stabled together or close herded and particularly when the biting fly population is abundant, commonly during the wet season (Luckins 1988).

The higher prevalence observed may be linked to the ecological conditions of the district where there are numerous animal watering points and the existence of big and medium sized trees and shrubs (Abule et al. 2007). A high sensitivity (86 to 100\%) of CATT/T.evansi test was reported from different geographical regions of the world (AbdelRady 2008). Risk factors to sampling of surra are rainy season which is a great time for Tabanus fly that prefer watery habitat, near a river, or other places that allow it to proliferate. Increasing fly population is usually followed by increasing cases of surra, especially in areas where the host animal habitat coexist with flies. In addition to the season, the wind factor is also influential in the spread of flies Tabanus. Other factors such as age and the livestock conditions that might cause stress such as malnutrition, pregnancy, and fatigue could be a trigger factor Surra disease. A tendency for infection rate to increase with age. This could be due to larger scale movement, which increases the risk of infection in adult (Bhutto et al. 2010; Tadesse et al. 2012).

Sensitivity of CATT/T. evansi RoTat 1.2 in the present study was found to be $72 \%$ sensitivity of CATT/T. evansi. A lower sensitivity or a high false negative result of CATT test in the present study might result from the following likely scenarios (Hagos et al. 2009). A nonRoTat 1.2 T.evansi isolates (T. evansi type B) might have existed from cattles of the study area because, a number of $T$. evansi type B isolates has been reported not to express the RoTat 1.2 VAT and serological tests based on RoTat 1.2 of T. evansi remained 
negative (Ngaira et al. 2005). Therefore, an emphasis is necessary to address the problem of diagnosis of $T$. evansi in the region. It is also important to note that serological tests need to be validated and standardized, if they are to be suitable for correct identification of infected animals, cross evaluation in different laboratories is thus required.

\section{CONCLUSION}

Serology prevalence to surra in Lombok Island was considerably high. Even though CATT/T. evansi technique is sensitive and suitable for mess screening, how ever is not always able to distinguish current from past infection. In addition, two or more technique should be used to diagnose reservoir host in Lombok island and for animal with sero negative should be re-tested after 30 days from the first examination due to serological latency.

\section{ACKNOWLEDGEMENT}

The author say thank to Eko Setyo Purwanto, Farlin Nefo, Edi Satria on technical assistance in the laboratory.

\section{REFERENCES}

Abdel-Rady A. 2008. Epidemiological studies (parasitological, serological and molecular techniques) of Trypanosoma evansi infection in camels (Camelus dromedarius) in Egypt. Vet World. 1:325-328.

Abule E, Snyman HA, Smit GN .2007. Rangeland evaluation in the middle Awash valley of Ethiopia: I. Herbaceous vegetation cover. J Arid Environ. 70:253-271.

Aquino LPCT, Rosangela ZM, Karen RL, Luiz CM, Garcia MV, Gustavo PB. 2010. Antiigenic characterization of Trypanosoma evansi using sera from experimentally and naturally infected bovines, equines, dogs and coatis. Rev Bras Parasitol Vet. 19:112-118.

Aregawi WG, Kassa ST, Tarekegn KD, Brehanu WT, Haile ST, Kiflewahid FZ. 2015. Parasitological and serological study of camel trypanosomosis (surra) and associated risk factors in Gabi Rasu Zone, Afar, Ethiopia. 7:234-240.

Babeker EA, Elrasoul YMH. 2014. Incidence and treatment of camel trypanosomosis (guffar) in West Omdurman in Sudan. J Anim Feed Res. 4:74-82.

Bajyana SE, Hamers R. 1988. A card agglutination test (CATT) for veterinary use based on an early VAT RoTat 1.2 of Trypanosoma evansi. Ann Soc Belg Med Trop. 68:233-240.

Bhutto B, Gadahi JA, Shah G, Dewani P, Arijo AG .2010. Field investigation on the prevalence of trypanosomiasis in camels in relation to sex, age, breeds and herd size. Pak Vet J. 30:175-177.

Birhanua H, Rogé S, Simon T, Baelmans R, Gebrehiwot T, Goddeeris BM, Büscher P. 2015. Surra SeroK-SeT, a new immunochromatographic test forserodiagnosis of Trypanosoma evansi infection in domestic animals. Vet Parasitol. 211:153-157.

Brown C, Torres A. 2008. Foreign animal diseases. 7th Ed. St. Joseph (US): Animal Health Association.

Buscher P. 2014. Diagnosis of African trypanosomiasis. In: Magez S, Radwanska M, editors. Trypanosomes and trypanosomiasis. Wien (Austria): Springer-Verlag. p.189-216.

CFSPH. 2015. Surra. Iowa (US): The Center for Food Security and Public Health.

Desquesnes M, Helzmuller P, Lai DH, Dargantes A, Lun ZR, Jittapalapong S. 2013. Trypanosoma evansi and surra: A review and perspectives on origin, history, distribution, taxonomy, morphology, hosts, and pathogenic effects. Biomed Res Int. 2013:194176. 
Dinas Peternakan Sumba Timur. 2012. Kejadian surra di Sumba Timur. Sumba Timur (Indonesia): Dinas Peternakan Sumba Timur.

Eyob E, Matios L. 2013. Review on camel trypanosomosis (surra) due to Trypanosoma evansi: Epidemiology and host response. J Vet Med Anim Health. 5:334-343.

Hagos A, Yilkal A, Esayass T, Alemu T, Fikru R, Feseha G, Goddeeris BM, Claes F. 2009. Parasitological and serological survey on trypanosomis (surra) in camels in dry and wet areas of Bale Zone, Oromyia Region, Ethiopia. Rev Méd Vét. 160:569-573.

Horn D. 2014. Antigenic variation in Africantrypanosomes. Mol Biochem Parasitol. 195:123-129.

Kertawirawan PA, Adijaya MR. 2012. Efektivitas penggunaan ivermectin untuk pengendalian parasit cacing pada usaha tani penggemukan sapi Bali. Seminar Nasional Teknologi Peternakan. hlm 48-55.

Luckins AG. 1988. Trypanosoma evansi in Asia. Parasitol Today. 4:137-142.

Mabey D, Peeling RW, Ustianowski A, Perkins MD. 2004. Diagnostics for the developing world. Nat Rev Microbiol. 2:231-240.

Magnus E, Lejon V, Bayon D, Buyse D, Simarro P, Verloo D, Vervoort T, Pansaerts R, Buscher P, Van Meirvenne N. 2002. Evaluation of an EDTA version of CATT/T. bruceigambiense for serological screening of human blood samples. Acta Trop. 81:7-12.

Ngaira JM, Olembo NK, Njagi ENM, Ngeranwa J. 2005. The detection of non-RoTat 1.2 Trypanosoma evansi. Exp Parasitol. 110:30-38.

OIE. 2012. Trypanosoma evansi infection (surra) by the World Assemblyof Delegates of the OIE in May 2012. Terrestrial Manual Chapter 2.1.17: Office International Des Epizooties. Rome (Italy): FAO.

Patra AK. 2007. Nutritional management in organic livestock farming for improved ruminant health and production an overview. Livest Res Rur Develop 19:1-21.

Radostits OM, Gay CC, Hinchcliff KW, Constable PD. 2007. Veterinary medicine. $10^{\text {th }}$ Ed. Philadelphia (US): Saunders Ltd.

Reid SA. 2002. Trypanosoma evansi control and containment in Australasia. Trends Parasitol. 18:219-24.

Roge S, Baelmans R, Claes F, Lejon V, Guisez Y, Jacquet D, Büscher P. 2014. Development of a latex agglutination test with recombinant variant surface glycoprotein for serodiagnosis of surra. Vet Parasitol. 205:460-465.

Santosa S, Agus S, Ratih W. 2013. Analisis potensi pengembangan usaha peternakan sapi perah dengan menggunakan paradigma agribisnis di kecamatan musuk Kabupaten Boyolali. Bul Peternakan. 37:125-135.

Sudarisman. 2006. Pencegahan penyakit virus pada hewan dengan vaksin mucosal. Wartazoa 16:181-189.

Sutama IK. 2008. Pemanfaatan sumberdaya ternak lokal sebagai ternak perah mendukung peningkatan produksi susu nasional. Wartazoa. 18:208-217.

Tadesse A, Omar A, Aragaw K, Mekbib B, Sheferaw DA. 2012. Study on camel trypanosomosis in Jijiga Zone, Eastern Ethiopia. J Vet Adv. 2:216-219.

Tran T, Claes F, Verloo D, De GH, Büscher P. 2009. Towards a new reference test for surra in camels. Clin Vaccine Immunol. 16:999-1002. 


\section{DISCUSSION}

\section{Questions}

1. The CATT useless for diagnostic tools what do you think?

2. How much the surra desease found in Indonesia?

3. How is the procedure of CATT, is the serum taken directly from the field?

4. What is an advantage of using CATT for surra test?

5. What type of medicine used for surra?

6. What is medicine for surra preventive and how much the dose for preventive?

\section{Answers}

1. The CATT can be used to test for screening only

2. Surra desease already found in some part of Indonesia, however there is no research undertaken about surra disease in Bali

3. In CATT method, blood from field is transported to Laboratorium by using ice box, then centrifuge to separate the serum. The serum then is used in CATT test.

4. The CATT test is faster and cheaper compared to other test. It is applicable in the field and do not need an expert to do the test

5. Many type of medicine are available for surra. However, due to the resistance cases to surra medicines in the field, the type of medicine will be used must be examined first

6. The dose for surra preventive is depend on the type of medicine used 